\title{
THE ENVIRONMENTAL EFFECTS OF THE AIR SHOCK GENERATED BY
} BLASTING

\author{
Vedat DENIZ1* ${ }^{*}$, Orçun Tugay DENIZ ${ }^{2}$ (D) \\ 1Engineering Faculty, Hitit University, 19030, Çorum, Turkey \\ vedatdeniz@hitit.edu.tr \\ 2Department of Mining Engineering, Hacettepe University, 06800, Ankara, Turkey \\ tugayorcun@gmail.com
}

Received: 26.10.2017, Accepted: 22.11.2017

*Corresponding author

doi: $10.22531 /$ muglajsci.346717

\section{Abstract}

The air shock induced by blasting may vary significantly at or around a quarry depending on several parameters such as the amount of explosive charge, the horizontal distance between the blast and the seismograph and the weather conditions. Therefore, evaluation of air shock condition at or around a quarry is necessary.

In this study, whether the relationship between the air shock and the horizontal distance, towards the settlement areas due to blasting operations in a quarry belongs to Corum Votorantim Cement Plant, has been investigated. The method of study is to perform in-situ air shock measurements in order to investigate the effect of the blast induced air shocks from different distances. Eighteen (18) different shots were organized in separate parts of the quarry and air shock values were taken as twenty five (25) different events from various distances. From the results of the statistical analysis, the air shock equations were obtained from scaled distances and the horizontal distance between the shot point and the measurement point from the blasting in the quarry with good coefficients of correlation as 0.82 and 0.78 , respectively.

Keywords: Blasting, Environmental effect, Air shock, Residential area

\section{PATLATMALARDA ORTAYA ÇIKAN HAVA ŞOKU'NUN ÇEVRESEL ETKİLERİ}

\section{$\ddot{0} \mathbf{z}$}

Patlatmanın sebep olduğu hava şoku, patlayıcı yük miktarı, patlama ve sismograf arasındaki yatay mesafe ve hava koşulları gibi çeşitli parametrelere bağlı olarak, taş ocağında veya ocağın çevresinde önemli ölçüde farklılıklar gösterebilir. Bu nedenle, bir taş ocağında veya çevresinde bir hava şoku durumunun değerlendirilmesi gereklidir.

Bu çalıșmada, Çorum Votorantim Çimento fabrikasının kalker ocağında patlatma çalıșmalarından kaynaklanan hava șoku, ișletmenin yakınında bulunan şantiye binalarına ve daha uzakta olan konutlara bir zarar verip vermeyeceği araștırılmıştır. Saha çalışması kapsamında 18 adet patlatmanın 25 farkl hava şoku ölçümü değişik mesafelerden alınarak sahanın ölçekli mesafe hava şoku - ilișsisi araștırılmıștır. İstatistiksel analiz sonuçlarına göre, taş ocağında patlatılma sonucu elde edilen hava şoku değerleri ile ölçekli mesafeler ve atış noktası ile ölçüm noktası arasındaki yatay mesafeler arasındaki ilişskilerden sırasıyla 0.82 ve 0.78 üzeri iyi korelasyon katsayıları ile hava şoku denklemleri elde edildi.

Anahtar Kelimeler: Patlatma, Çevresel etki, Hava şoku, Yerleşim alanı

\begin{abstract}
1. Introduction
\subsection{Environmental Factors Caused by Blasting}

In recent years, the subject between the quarry owners' brains as much as operational efficiency is environmental effects resulting from the working conditions. Especially with the increase of urbanization, quarries are surrounded by settlement units, and they are exposed to various complaints mainly ground vibrations and air shock such as; avalanche formation of rocks, dust formation, loss of underground water resources, inconvenience to urban settlements of transportation vehicles, image pollution of the quarries etc. In blasting operations, blasting patterns, type of explosive, and quantity are becoming important in terms of the efficiency of blasting, while ignition systems are becoming more important in terms of environmental effects and safety, especially air shock and ground vibrations. Due to the erroneous blasting practices, the people around many quarries have been sensitized, and therefore they are beginning to feel uncomfortable from the slightest ground vibration and air shock (noise) [1-3].
\end{abstract}

One of the most important elements expected from a good explosion is that the explosion is made safe from environmental influences. Taking into account such environmental considerations, it is very important for being able to predict in advance the maximum explosive amount that will be used for any delay and to perform controlled blasting in terms of not being affected by air shock and vibration that will occur at a certain distance from the blasting source.

It is natural that environmental residents do not know at what level air shock can damage their houses. Because of this lack of information and the fact that they act with assumptions of wrong information, they are beginning to believe that air shocks will cause damage and then they complain. Some malicious people are complaining, despite they are not really affected by quarrying activities to be provided a variety of benefits from owners of quarries [3-4].

It should not be overlooked that some of the complaints may also be real and damage complaints. Removing damages caused by ground vibrations and air shocks or paying compensation can result in higher costs to the quarry owner. Therefore, it is 
necessary to investigate whether the complaints are justified in order to protect both the settlements in the surrounding area and to ensure that the quarry owners are as economical as possible. The only way to do this is to apply appropriate methods that result in in-situ engineering measurements [4-7].

\subsection{Environmental Factors Caused by Air Shock}

Blasting made for the production of aggregate in quarries is indispensable because of the economic gains it brings. However, flying rocks, dust formation, ground vibrations and air shocks, which are the result of detonations, are a major problem for the settlement around the blasting area. These problems are mainly ground vibrations and air shocks. The administrations have to carry out the necessary measurements and evaluation activities in order to keep these negative effects of blasting at a minimum level and not to damage the environment [2].

The usual method of determining the effects of blasting on surrounding settlements and minimisation should be determined of the highest particle velocities with a seismograph and determination of the land coefficients for the route between the blasting point and the measurement point, and then, it should be determined by the maximum amount of explosives that can be safely blasted at one delay time depending on the distance by the provided formula of the measurements from determining the propagation rule of the vibrations [5, 8-9].

Air shock is one of the undesirable effects and that occurs with the blasting. Air shock is a source of complaints from people in the nearby settlements due to the sudden and strong noise it creates, even if it rarely causes damage to the buildings. The level of air shock that is generated by blasting is expressed in decibels $(\mathrm{dB})$ and creates damage on the building depending on its decibel sizes [3].

Air shock is the pressure waves that emanate from the air, caused by blasting. Because it is not the shear resistance of the air, they are only carried pressure waves. Air shock waves generally spread 5-20 times slower than ground vibration waves and fades as it moves away from the blasting site. The most important parameters to be investigated in the studies on air shock are the amount of explosives used per delay time and the distance between blasting site and the measuring station. Air shock caused by detonation in a quarry or its surroundings; the amount of explosives, the distance between the blasting site and the measurement site, and the meteorological conditions vary. For this reason, it is necessary to evaluate and determine the noise situation of any quarry or surrounding area [10].

In the study many researchers have done, it shows that electronic capsules are much more advantageous both in terms of ground vibration values and air shock values $[3,7]$.

Deniz (2016)[7] has shown that the electronic ignition system to reduce noise complaints in the surrounding settlements can generate much less air-shock than the non-electrical ignition. During electronic explosive operations, the perception levels of people who previously reported discomfort in the settlements were investigated and it had been stated that they felt nothing. $\mathrm{He}$ said that the workers in the quarry were more uncomfortable with the perception of the breaker' noise according to the electronic explosion on the working days to the breaking of big blocks by wearing the breaker. I addition, he noted that, despite the use of electronic capsules for more holes and more ANFO (main charge) in total, the peak particle velocities $(\mathrm{mm} / \mathrm{sec})$ and air shocks $(\mathrm{dB})$ were reduced significantly.
In this study, a practical evaluation was made in terms of air shock values which are important environmental factors in blasting process of non-electric capsules which are widely used in blasting in the mining sector in Turkey.

\section{Working Region}

The quarry of the Çorum Votarantim Cement Factory, which is the study site, is located $5 \mathrm{~km}$ southeast of the Çorum provincial center and $1100 \mathrm{~m}$ above sea level (Figure 1). It is $1500 \mathrm{~m}$ south of the Çorum-Samsun road, $2100 \mathrm{~m}$ southeast of the Cement Factory, $2500 \mathrm{~m}$ east of the Çorum Merkez Bahçelievler District and 1100 m east of the Melikgazi Vineyards, 1400 m north-east of the Disaster Houses, $780 \mathrm{~m}$ south of the Melikgazi Mausoleum and $500 \mathrm{~m}$ east of the Çorum Municipality's Quarrying Site buildings.

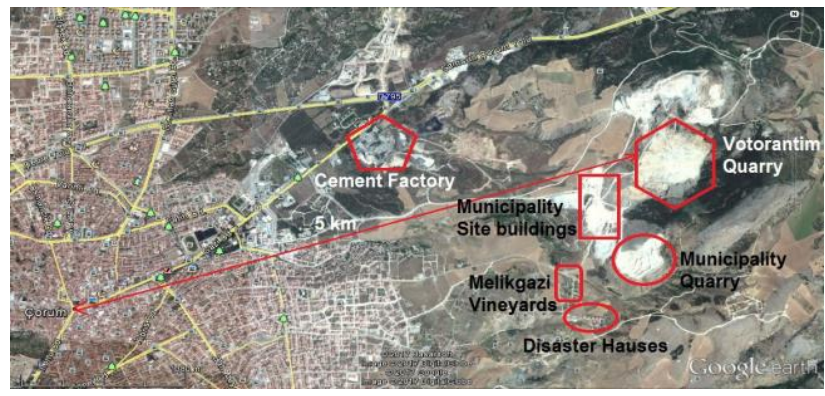

Figure 1. Satellite image of work area

\section{Research Method}

Within the scope of this research, air shocks which occur as a result of bastings in the quarry belongs to the Çorum Votorantim Cement Factory, near Çorum's city center, whether or not it will be at levels that could cause damage to buildings in the Melikgazi Vineyards (Figure 2) and construction site (administrative building, mess hall, weigh-bridge, transformer etc.) at the Çorum Municipality quarry (Figure 3).

This study includes an assessment of whether or not it will be at harmful levels of air shocks on the buildings (administrative building, dining hall, weighbridge, transformer etc.) in the Melikgazi Vineyards and the Çorum Municipality's quarry because of blasting operations in the quarry of the Corum Votorantim Cement Factory.

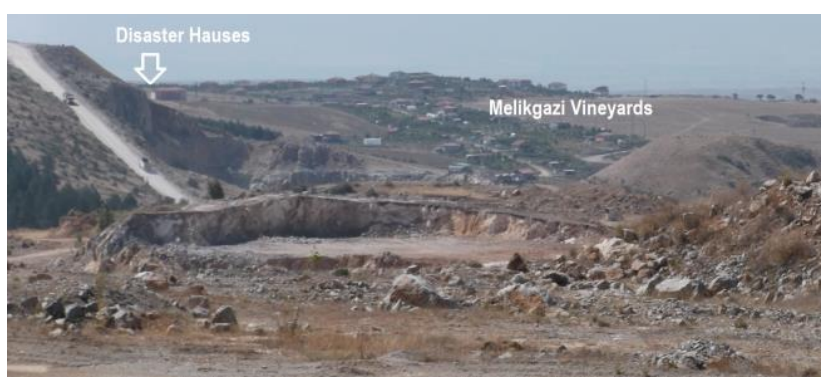

Figure 2. The view of residential areas close to the quarry

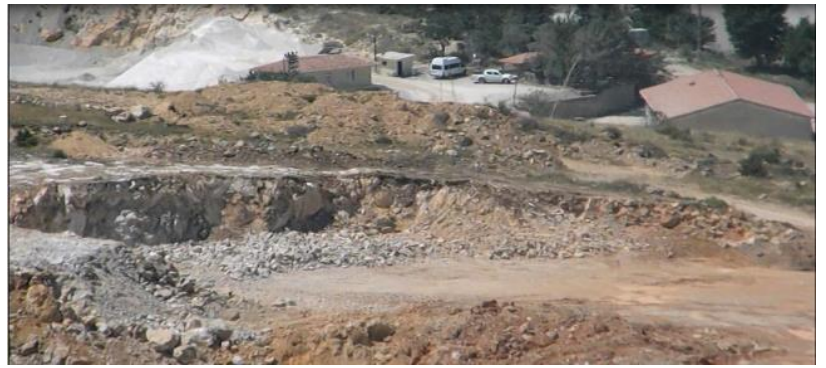

Figure 3. The view of Çorum Municipality's building site 
As shown in Figure 4, there are seven (7) benches in operation in the quarry and usually blasting at the 3rd, 4th and 5th benches. In the quarry, the height of each bench is almost equal to10 $\mathrm{m}$. In the blasting operation, the drilling operation was carried out with the Furukawa brand drilling.

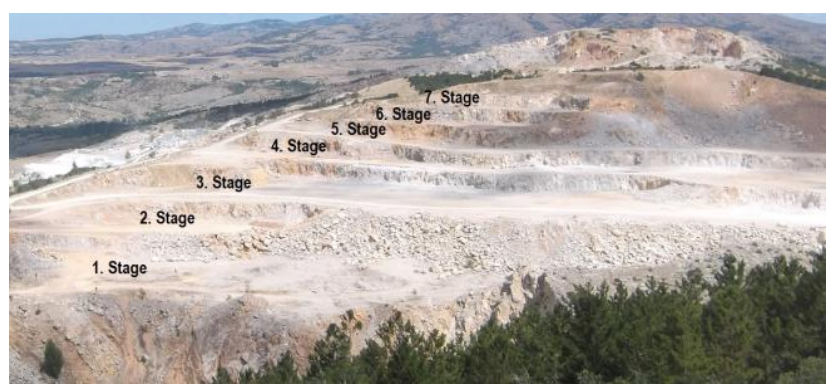

Figure 4 . The view of the stages of the quarry

ANFO was used as an explosive substance and EMULITE dynamite was used for feeding the blasting process in the quarry. The ignition system was done with delayed capsules, non-electrically. The spacing and the burden distance is $2.5 \times 2.5 \mathrm{~m}$, and the holes are drilled in the cross plane. The stemming length is $2.5 \mathrm{~m}$ and the sub-drilling is $1 \mathrm{~m}$. In determination of the maximum explosive charge per delay; the dynamite weight $(0.5 \mathrm{~kg})$ used for feeding and ANFO were taken into consideration, while the distance between the blasting site and the measuring station has been found by GPS. One Instantel Micromate model seismometer and two Instantel Minimate-Blaster model seismometers were used for air shock measurements which occur by blasting (Figure 5). The obtained data was evaluated by computer programs and reported work by an office program.

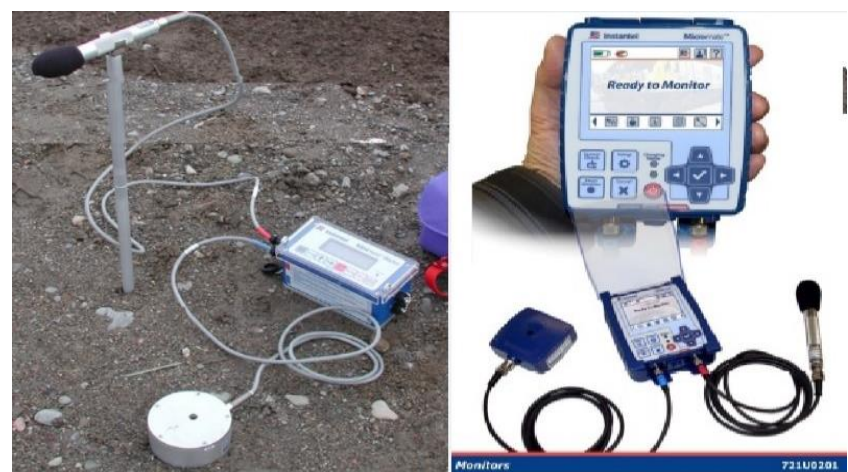

Figure 5. Instantel Minimate Blaster model and Micromate model vibration and air shock measurement devices

\subsection{Environmental Effects of Air Shock (Noise)}

In blasting applications, energy waves propagate in the air occur, which is called high air-shock pressure or sudden noise. Air shock resulting from the blasting process in or around an open pit mine may vary depending on many factors such as the amount of ignited explosive, the distance between the blasting site and the measurement site, and the meteorological conditions. For this reason, it is necessary to evaluate and determine the noise situation in or around any open pit mine.

In the sound levels above $145 \mathrm{~dB}$ at the measuring station during the blasting, air shocks may cause discomfort on the people due to the noise, breakage of window-glass and damage to the buildings [11].

In the noise regulation in our country, there is no limit value for air shock evaluation from the blast-induced, but it is determined that any kind of impact noise cannot exceed $140 \mathrm{~dB}$ (A) as the upper level of damage. In this study, it is used the 133
$\mathrm{dB}(\mathrm{C})$ limit value set for the noise in the USA noise regulation because the Turkish noise regulation does not set a limit for the noise caused by blasting.

The most important parameters to investigate on air shock studies are the amount of explosives (W) used per delay time and the distance to the measuring station (R). In addition, the stemming height is also an important parameter. The level of air shock that accompanies the decrease of the stemming height of compression increases. The pre-split blast holes carry the risk of producing a high level of air shock, as they are impenetrable due to the applied blasting technique [10].

Air blast propagation is also affected by meteorological conditions, especially wind speed and direction. Wind speed, wind direction and temperature inversion are important parameters [10]. For this reason, meteorological conditions also should be taken into consideration in the assessment of airborne emissions. In this study, only the measurements on windless days were taken into account in the calculations, by not taking into account the measured values on the days when the wind effect was excessive.

For the ground vibrations, a square root equation was used which is the most frequently in similar studies in determining the scaled distance (SD) [12].

$\mathrm{SD}=\mathrm{R} / \mathrm{W}^{1 / 2}$

The Scaled Distance (SD) method is used to compare the air shock waves from detonated explosives at different quantities and at different distances. Since the noise data are less distributed in air shock propagation, cube root $(1 / 3)$ instead of the square root $(1 / 2)$ type scaled distance method is preferred [5]. This method assumes occurrences of equivalent air shock waves at equivalent scaled distances $[5,8]$.

$\mathrm{SD}=\mathrm{R} / \mathrm{W}^{1 / 3}$

where;

R: distance (m)

W: maximum charge per delay time $(\mathrm{kg})$

SD: Scaled distance (m/ $\mathrm{kg}^{1 / 2}$ for ground vibration; $\mathrm{m} / \mathrm{kg}^{1 / 3}$ for air shock)

During the field study, eighteen (18) shots with the NONEL capsules were monitored and 25 events were recorded by 3 vibration and air shock monitors. The coordinates of monitor stations and shot points were determined and are shown in Figures 6-8 by GPS (Global Positioning System), and blasting patterns were recorded for each shot in the quarry belongs to the Çorum Votorantim Cement Corporation.

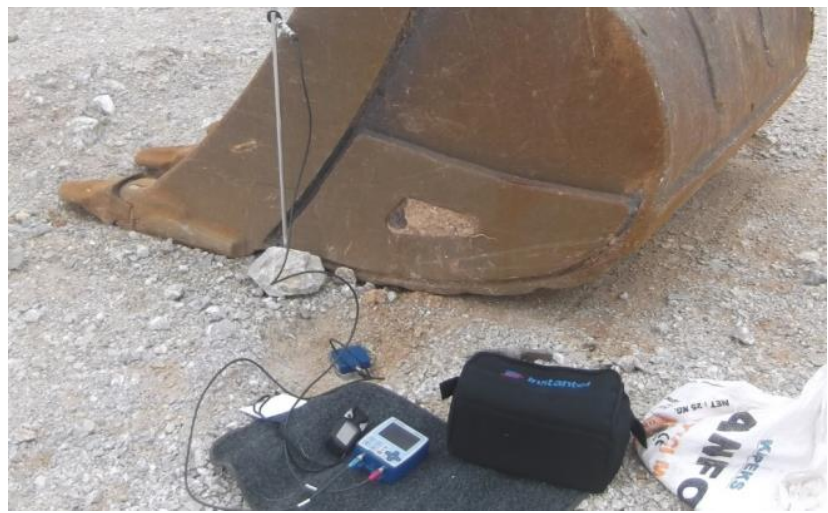

Figure 6. Detection of a monitor station point by GPS 


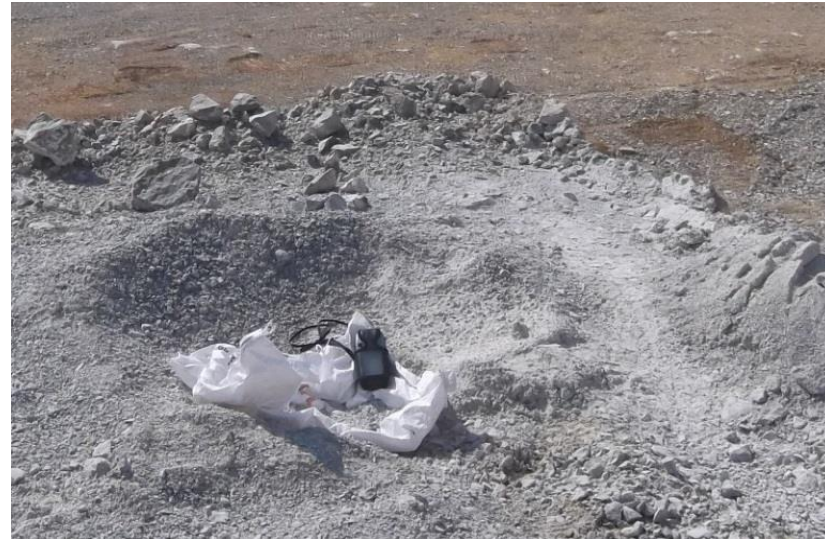

Figure 7. Detection of a shot point by GPS

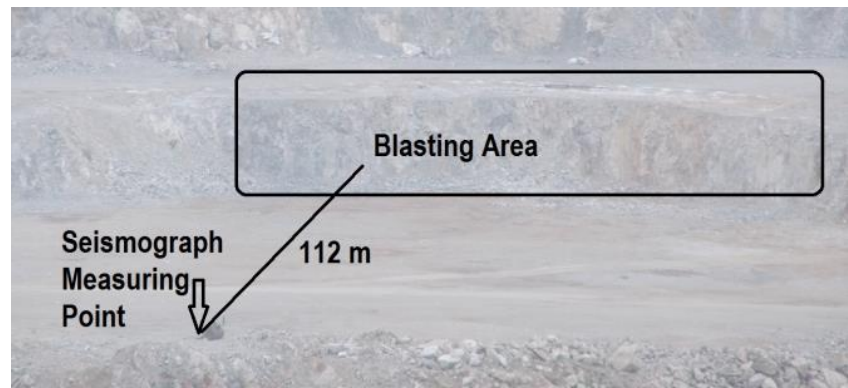

Figure 8. The view of the distance of between measuring point and blasting area

In air shock measurements, Instantel Micromate and Minimate Blaster model seismographs, used to measure ground vibrations (shakes) as digital seismographs, were also used. The devices can measure air shock (noise) at a minimum of 88 $\mathrm{dB}$ and a maximum of $148 \mathrm{~dB}$. Air shock recordings recorded by the devices have been transferred to the computer via the software provided with the seismographs.

After the measurements on the air shock were made, the relationships with the scaled distance were examined for both square root $(1 / 2)$ and cube root $(1 / 3)$, and the results were given in Figures 9 and 10.

As can be seen from Figure 9 and Figure 10, similar to the findings of researchers on the subject, the cube root $(1 / 3)$ in the relation between the air shock and the scaled distance gave a better than the square root $(1 / 2)$.

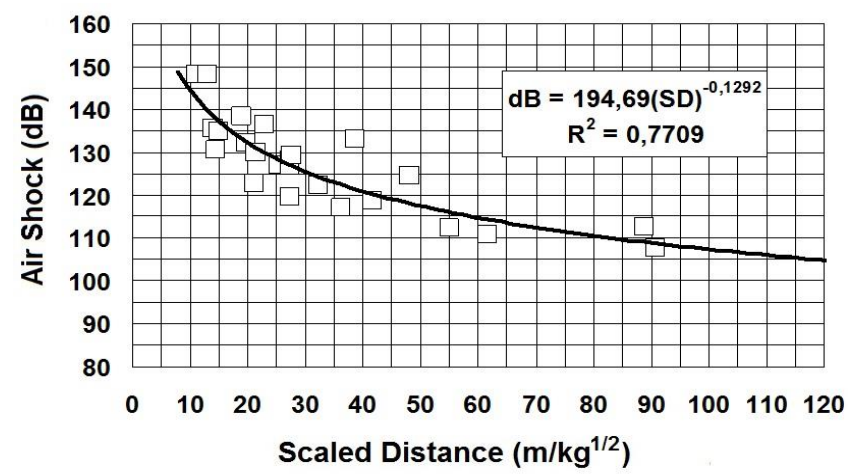

Figure 9. The relationship of between the air shock and the scaled distance $\left(\mathrm{m} / \mathrm{kg}^{1 / 2}\right)$

When all records received on windless days were evaluated (Figures 9-10); the air shocks recorded in the direction of the building site are totally in accordance with the USA standard since they are below $122 \mathrm{~dB}$. In other words, all values recorded in the direction of the site buildings did not exceed the limit value of $133 \mathrm{~dB}$ given for damage value in the USA. In addition, as shown in Figures 9-10, the instantaneous damage limit value of $140 \mathrm{~dB}$ in Turkey has been exceeded seven (7) times. When these exceeded records were examined, they were found to be within the quarry and be very close to the distance (between 79 $\mathrm{m}$ and $256 \mathrm{~m}$ ) between the shot point and the measuring point, and additionally when the boulders were secondary detonated. The limit value of the USA standard, $133 \mathrm{~dB}$, has been exceeded eighteen (18) times, and these measurement values have also been found to be very close to the distance between the measuring point and the shot point, and be within the quarry.

In Figure 11, when the relationship between the obtained air shock values $(\mathrm{dB})$ and the distance in direct meters is examined, the air shock value decreases exponentially when the distance increases. From records obtained data showed that the air shock values were fell below $140 \mathrm{~dB}$ after $80 \mathrm{~m}$, and after 300 $\mathrm{m}$, it definitely fall below $119 \mathrm{~dB}$. The shock value has been determined to have fallen below $100 \mathrm{~dB}$ after $750 \mathrm{~m}$. The 107 $\mathrm{dB}$ value recorded after 630 meters is enough to not cause any disturbance on the settlements, and it is also within the permitted limits as determined by both the USA and Turkey.

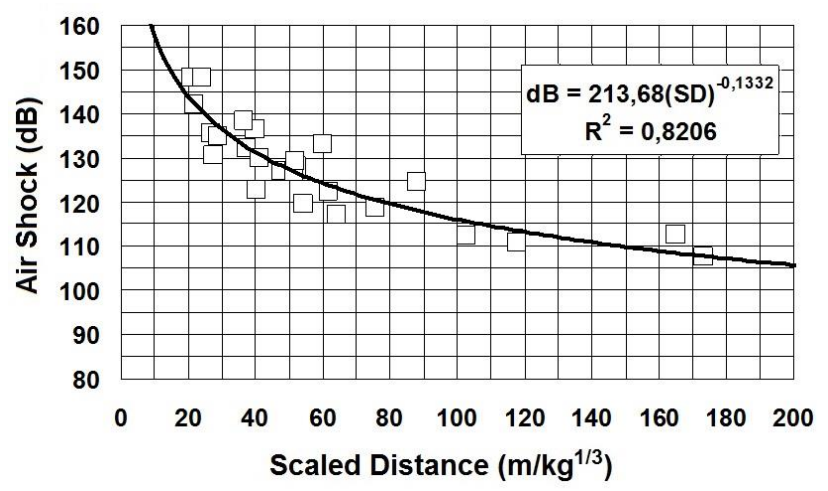

Figure 10. The relationship of between the air shock and the scaled distance $\left(\mathrm{m} / \mathrm{kg}^{1 / 3}\right)$

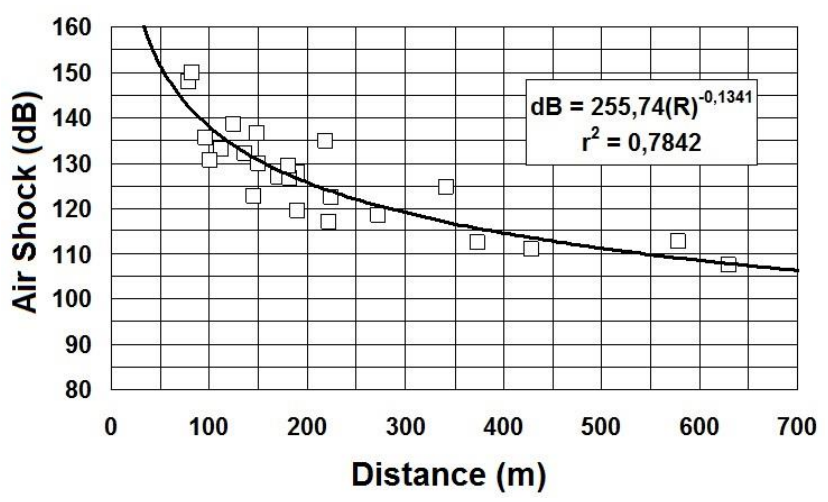

Figure 11. The relationship of between the air shock and the distance $(\mathrm{m})$

When Figure 10 is examined, the cube root $(1 / 3)$ relationship between the peak particle velocity (PPV) and the scaled distance (SD) as accepted by many researchers was obtained with a good regression coefficient of 0.82 in this study. In Figure 11 , it is found being, that the air shock (noise) values can be estimated directly in $\mathrm{dB}$ depending on the distance between the shot point and the measuring point with a lower regression coefficient $\left(r^{2}=0.78\right)$.

As a result of the present measurements, it was determined that the blasting in the Votorantim Corum Cement's quarry were within the limits allowed for the Melikgazi Vineyards and the 
Disaster Houses located at $1450 \mathrm{~m}$ to $1600 \mathrm{~m}$, and these values will not possible to exceed the limit values. Additionally, it was also found that they will also be within the permissible limits for buildings site belongs to the Corum Municipality's quarry located $450 \mathrm{~m}$ to $950 \mathrm{~m}$ away from the Çorum Votorantim Cement's quarry. Although the air shock observation records are in compliance with the regulations, the air shock dispersion dynamics must be examined in detail to fully avoid problems with noise in the future. In addition, it is proposed with more careful stemming and with limits of $50 \mathrm{~kg}$ of the explosive amount used per delay time to reduce the risk of any future problems.

Damage to the environment caused by air shocks generated during blasting often occurs as a psychological disturbance in people. The less air shock can be occurred, the less perception will be, and the complaints will be removed.

No limit value was set for the air shock (noise) in the specifications that the contracting firm was based on the conduct of the work. In fact, this value should be asked not to exceed $125 \mathrm{~dB}$ due to the sensitivity of the environmental residents by the Çorum Votorantim Cement Factory. In addition, it should be wanted from the contractor firm the application of stemming lengths equal to or greater than the burden distance (slice thickness) to prevent air shock (noise) and fly rock.

\section{Conclusion}

Air shock can be controlled to environmental limits by first of all understanding the causes and factors contributing to air shock and then using the techniques that have been developed to eliminate the causes. Importantly, air shock can be controlled to environmental limits if the factors contributing to air shock are recognised and quantified by appropriate models. Techniques have been developed to overcome some of the causes of high air shock levels but the importance of controlling the stemming height and the explosive charge process to achieve the design specification cannot be emphasised enough. In this study, air shock values were recorded between 108-127 $\mathrm{dB}$ during the blasting in the direction of the building site (excluding seven units measured the nearest between the shot point and measurement station within the quarry). These values indicate that the blasting will not be causing any damage to the facilities and structures in the vicinity of 450-600 $\mathrm{m}$ than the selected measuring stations, and glass breakage and disturbances from over noise will not occur.

Even if there are no hazards due to the fact that the distance between the blasting point and the nearest settlement is 1400 $\mathrm{m}$, there should be carefully adjustments to stemming heights, and there should be conveyor belts laid on the holes for the prevention of possible damage to drilling and working machines within the quarry from fly rocks during blasting.

\section{Acknowledgment}

This study was carried out with a research project (Project No: MU19005.15.01) under the 19005 University-Sector Cooperation supported by the Hitit University Scientific Research Fund (BAP).

In addition, we would like to thank the Çorum Votorantim Cement Plant officials and employees for their assistance in the field works and other activities during this research.

A part of this manuscript is presented at ISME2017.

\section{References}

[1] Deniz, V. ve Deniz, O.T. "Corum çimento taș ocağında yapılan patlatmaların çevresel etkiler açısından değerlendirilmesi", 5. Madencilik ve Sempozyumu, Antalya, 2015a, 144-158,

[2] Deniz, V. ve Deniz, O.T. Çorum Belediyesinin taş ocağında patlatma kaynaklı titreșimlerin yönsel açıdan değerlendirilmesi, 5. Madencilik ve Sempozyumu, Antalya, 2015b, 159-174.

[3] Deniz, V. “Çorum Belediyesinin taş ocağında elektronik ve elektriksiz patlatma sistemlerinin hava şoku ve yer sarsıntısı açısından karşılaştırması", 8. Uluslararası Kırmataş Sempozyumu, Kütahya, 2016a, 186-194.

[4] Uyar, G.G., Erkoç, Ö.Y. ve İpek, T. "Patlatmalar sonucu çevreye verilen sarsintılar üzerinde bir yorum", 2. Ulusal Kırmataş Sempozyumu, İstanbul,1999, 255-260.

[5] Dowding C.H. Blast Vibration Monitoring and Control, Prentice-Hall, USA, 1985.

[6] Erkoç, Ö.Y., "Patlama ile çevreye verilen sarsintılar ve hasar kriteri üzerine bir araștırma", 3. Delme-Patlama Sempozyumu, , Ankara,1998, 129-139.

[7] Deniz, V. "Geleneksel ve elektronik ateșleme sistemlerinin karșılaștırması”, 8. Uluslararası Kırmataș Sempozyumu, Kütahya, 2016b, 195-207.

[8] Siskind, D.E., Stagg, M.S., Kopp, J.W. and Dowding, C.H., Structure response and damage produced by ground vibration from surface mine blasting, RI 8507, Bureu of Mines Report of Investigations, USA, 1980.

[9] Anderson, D.A. ,Winzer, S.R. and Ritter, A.P. "Blast design for optimizing fragmentation while controlling frequency of ground vibration", $8^{\text {th }}$ Conference on Explosives and Blasting Technique, New Orleans/USA, 1982, 69-89.

[10] Bilgikoçin, O. ve Bilgin, H.A., "Uşak Kıșladağ altın madeninde ön-kesme patlatmasından kaynaklanan hava şoku basıncı analizi", V. Delme Patlatma Sempozyumu, Ankara, 2007, 189-196.

[11] Kahriman, A., Çeltikçi, A., Bağdatlı, S., Ocak, İ., Özdemir, A., Sefer, İ. ve Sağlam, R., "Kuzey Marmara Otoyolu Projesi Odayeri-Paşaköy (3. Boğaz Köprüsü Dahil) Kesimi” Ömerli Köyü kalker ocağında yapılan açık ocak patlatmalarının çevresel hasar riski açısından analizi", 8. Delme Patlatma Sempozyumu, İstanbul, 2015, 277-284.

[12] Duwall, W.I and, Fogleson, D.E. Review of criteria for estimating damage to residences from blasting vibration, USBM-I 5968, USA, 1962. 